\title{
Caring Perawat di RSUD Tani dan Nelayan Kabupaten Boalemo
}

\author{
Dr. Hj. Rosmin Ilham, S.Kep., Ns., MM ${ }^{(1)}$, dr. Muhammad Nur Syukriani Yusuf, M.Med.Ed ${ }^{(2)}$ Risky \\ Inaku., S.Kep., $\mathrm{Ns}^{(3)}$ \\ ${ }^{1}$ STIKES Tanawali Persada Takalar \\ 2,3Program Studi Ilmu Keperawatan Universitas Negeri Gorontalo \\ Emai: $\underline{\text { rosmin_ilham@yahoo.com }}$
}

\begin{abstract}
Abstrak
Caring adalah sikap peduli, menghormati dan menghargai orang lain. Caring sangat dibutuhkan dalam tatanan layanan keperawatan, karena caring inti dari praktik keperawatan. Caring perawat merupakan perilaku perawat yang ditunjukan kepada pasien dalam memberikan asuhan keperawatan seperti memberi rasa nyaman, perhatian, peduli, terampil, memberi sentuhan, memenuhi kebutuhan pasien, serta mengunjungi pasien. Tujuan penelitian ini adalah untuk mengetahui gambaran caring perawat di RSUD Tani dan Nelayan Kabupaten Boalemo. Desain dalam penelitian ini menggunakan desain penelitian deskriptif. Populasi dalam penelitian ini adalah semua pasien rawat inap (interna kelas 1 dan 2, interna kelas 3, bedah, VIP, anak, dan ICU) di RSUD Tani dan Nelayan Kabupaten Boalemo yang berjumlah 247 responden. Sampel penelitian berjumlah 153 responden dengan teknik sampling propotional stratified sampling. Instrumen penelitian menggunakan kuesioner. Hasil penelitian ini menunjukan bahwa sebanyak 109 responden $(71,2 \%)$ caring perawat tinggi dan sebanyak 44 responden $(28,8 \%)$ caring perawat rendah. Kesimpulannya sebagian besar caring perawat di RSUD Tani dan Nelayan Kabupaten Boalemo tinggi. Saran bagi perawat perlu ditingkatkan lagi penerapan caring perawat dalam melakukan pelayanan terhadap pasien dan juga bisa dijadikan sebagai acuan untuk evaluasi kinerja perawat dalam memberikan pelayanan kesehatan kepada pasien minimal 6 bulan sekali.
\end{abstract}

Kata kunci: caring, perawat

\begin{abstract}
Caring is a caring attitude, respecting, and appreciating others. Caring is desperately needed in nursing service due the caring is the core of nursing practice. Nurse caring is nurse behavior addressed to patients is providing nursing care namely providing a sense comfort, paying attention, caring, skillful, giving touch, fulfilling pattient`s needs, as well as visiting patients. The research aimed to find out the overview of nurse`s caring behavior at RSUD Tani dan Nelayan, Boalemo District. It applied descriptive research design. The population of this research was all of the inpatient (Interna Class 1, Class 2, and Class 3, Surgical, VIP, Chlidren, and ICU) at RSUD Tani dan Nelayan, Boalemo District which amounted to 247 respondents. Moreover, the research samples were 153 respondents selected through propotional stratified sampling technique. Meanwhile, the research instrument employed questionnaire. The finding revealed that there were 109 respondents $(71,92 \%)$ had high nurse caring behavior, and 44 respondents $(28,8 \%)$ had low nurse caring behavior. In conclusion, mostly nurse`s caring behavior at RSUD Tani dan Nelayan, Boalemo District was in high category. It was recommended to the nurse to improve further the application of nurse caring behavior in providing service to patients, and it also could be utilized as a reference of nursing performance evaluation in proyiding health service to patients at least once in six months.
\end{abstract}

Keywords: Caring, Nurse

\section{Pendahuluan}

Rumah sakit memiliki peran yang sangat strategis dalam upaya mempercepat peningkatan derajat kesehatan masyarakat. Paradigma baru pelayanan kesehatan mengharuskan rumah sakit memberikan pelayanan berkualitas sesuai dengan kebutuhan dan keinginan pasien dengan tetap mengacu pada kode etik profesi. Dalam perkembangan teknologi yang pesat dan persaingan yang semakin ketat, maka rumah sakit dituntut untuk terus melakukan 
peningkatan kualitas pelayanannya.

(Kemenkes RI, 2010).

Perawat adalah individu (seseorang profesional) yang mempunyai kemampuan, tanggung jawab melakukan asuhan keperawatan yang telah lulus jenjang pendidikan keperawatan. Salah satu tindakan yang diharapkan adalah tenaga perawat dapat membina hubungan baik dengan pasien yaitu dapat melalui teknik dan sikap komunikasi serta berperilaku caring selama memberikan asuhan keperawatan kepada pasien agar kebutuhan pasien dapat terpenuhi. Salah satu cara mengatasi masalah tersebut yaitu dengan sikap caring. (Darmawan, 2017)

Caring merupakan sikap peduli, menghormati, dan menghargai oran lain. Caringsangat dibutuhkan dalam tatanan layanan keperawatan, karena caring merupakan inti dari praktek keperawatan. Caring merupakansuatu cara pendekatan yang dinamis, dimana keperawatan bekerja untuk lebih meningkatkan kepeduliannya kepada klien. (Purwaningsih, 2018)

\section{Menurut Supriatin (2015) tentang} caring perawat dari hasil penelitannya menunjukkan sebagian besar $(58,5 \%)$ caring perawat pelaksana masih kurang. Hal ini didapat terjadi karena kebanyakan perawat terlibat secara aktif dan memusatkan diri pada fenomena medik, seperti cara diagnostik dan cara pengobatan. Akibatnya, perawat kekurangan waktu dalam memberikan perhatian pada tugas care klien. Selain itu juga perawat lebih menekankan perilaku caring fisik daripada afektif. Pemenuhan kebutuhan biologis menjadi fokus utama perawat sehingga kebutuhan lainnya seperti kebutuhan psikologis, sosial, dan spiritual klien kurang mendapat perhatian.

Menurut Tiara dan Lestari (2014) dari hasil penelitiannya dari 96 responden didapaptkan juga bahwa sebagian besar respondennya merasa kurang puas dengan pelayanan caring perawat terhadap pasien sebesar 47 orang (49\%), yang cukup puas sebanyak 34 orang $(34,5 \%)$, dan responden sangat puas hanya 15 orang $(15,5 \%)$. Hal ini dikarenakan terdapat faktor lain yang mempengaruhi caring pada pasien seperti pengalaman dan faktor demografi responden dalam menerima pelayanan perawat. Dan biasanya juga seseorang pasien yang pada masa sehat terbiasa hidup dengan pelayanan yang sepenuhnya dipusatkan pada pemuasan semua keinginan, tentu sewaktu mendapat perawatan akan menuntut perlakuan yang sesuai dengan yang diperolehnya dalam kehidipan sehari-hari.

Berdasarkan hasil penelitian dari Sumartini (2017) menjelaskan bahwa caring tersebut dipengauhi oleh beberapa faktor yang menyebabkan penerapan caring oleh perawatadalah beban kerja, lingkungan, pengetahuan dan pelatihan caring. Dan adapula faktor yang mempengaruhi caring yaitu faktor internal daneksternal. Faktor internal yaitu persepsi, emosi, dan motivasi. Sedangkan faktor eksternal yaitu lingkungan sekitar, baik fisik maupun non fisik seperti : iklim, manusia, social, ekonomi, dan kebudayaan. 
Berdasarkan hasil data awal yang dilakukan oleh peneliti tanggal 19 oktober 2019 dilakukan pada 10 pasien diruang rawat inap RSUD Tani dan Nelayan Kabupaten Boalemo didapatkan sebanyak 3 pasien mengatakan bahwa perawat memberikan pelayanan dengan baik. Dari 3 pasien tersebut 2 diantaranya mengatakan perawat saat melakukkan tindakan selalu tersenyum, ramah, dan selalu menanyakan keluhan pasien yang dirasakan. Sedangkan 7 pasien menyatakan bahwa perawat masih kurang dalam memberikan pelayanan dikarenakan terlalu sibuk dengan urusannya sendiri dan perawat kurang bisa menyampaikan dengan jelas ketika memberikan pendidikan kesehatan atau informasi tentang penyakit pasien, dan kurang memperhatikan pasien terkait dengan keyakinan pasien. Dan juga dari 7 pasien tersebut 4 diantaranya juga mengatakan perawat kurang perhatian pada pasien, berbicara dengan nada keras. Dan disaat mintakan bantuan perawat tidak segera menolongnya malahan acuh tak acuh dengan keluhan pasien tersebut. Penelitian ini bertujuan untuk mengetahui gambaran caring perawat di RSUD Tani dan Nelayan Kabupaten Boalemo.

\section{Metode Penelitian}

Penelitian dilaksanakan di ruang rawat inap (interna kelas 1\&2, interna kelas 3, bedah, VIP, anak, dan ICU) RSUD Tani dan Nelayan Kabupaten Boalemo. Desain penelitian yang digunakan adal desain penelitian Deskriptif. Populasi dalam penelitian ini sebanyak 243 responden dan
Sampel adalah 153 responden yang ditentukan dengan teknik Stratified Propotional Sampling. Instrument yang digunakan dalam penelitian ini adalah lembar kuisioner dengan 41 pernyataan terdiri dari 29 pernyataan positif dan 12 pernyataan negatif.

\section{Hasil Penelitian}

Berdasarkan hasil penelitian yang dilakukan di RSUD Tani dan Nelayan Kabupaten Boalemo khususnya diruangan rawat inap diperoleh distribusi frekuensi responden sebagai berikut :

Tabel 1 Distribusi Responden Berdasarkan Umur Di RSUD Tani Dan Nelayan Kabupaten Boalemo

\begin{tabular}{|c|l|c|c|}
\hline No & Umur & $\mathbf{n}$ & $\mathbf{\%}$ \\
\hline $\mathbf{1}$ & $12-16$ Tahun & 2 & 1,3 \\
$\mathbf{2}$ & $17-25$ Tahun & 43 & 28,1 \\
$\mathbf{3}$ & $26-35$ Tahun & 63 & 41,2 \\
$\mathbf{4}$ & $36-45$ Tahun & 21 & 13,7 \\
$\mathbf{5}$ & $46-55$ Tahun & 19 & 12,4 \\
$\mathbf{6}$ & $56-65 T a h u n$ & 5 & 3,3 \\
\hline \multicolumn{2}{|c|}{ TOTAL } & $\mathbf{1 5 3}$ & $\mathbf{1 0 0}$ \\
\hline
\end{tabular}

Berdasarkan tabel 1 menunjukkan bahwa dari 153 responden yang diteliti, sebagian besar responden berumur antara 2635 tahun sebanyak 63 responden (41,2\%), dan paling sedikit yang berumur 12-16 tahun sebanyak 2responden $(1,3 \%)$.

Tabel 2 Distribusi Responden Berdasarkan Jenis Kelamin Di RSUD Tani Dan Nelayan Kabupaten Boalemo

\begin{tabular}{|c|l|c|c|}
\hline No & Jenis Kelamin & n & \% \\
\hline $\mathbf{1}$ & Laki-Laki & 60 & 39,2 \\
$\mathbf{2}$ & Perempuan & 93 & 60,8 \\
\hline \multicolumn{2}{|c|}{ TOTAL } & $\mathbf{1 5 3}$ & $\mathbf{1 0 0}$ \\
\hline
\end{tabular}


Berdasarkan tabel 2 menunjukkan bahwa dari 153 responden yang diteliti, sebagian besar responden berjenis kelamin perempuan sebanyak 93 responden $(60,8 \%)$, dan yang berjenis kelamin laki-laki sebanyak 60 responden $(39,2 \%)$.

Tabel 3 Distribusi Responden Berdasarkan Pendidikan Di RSUD Tani Dan Nelayan Kabupaten Boalemo

\begin{tabular}{|c|l|c|c|}
\hline No & Pendidikan & n & \% \\
\hline $\mathbf{1}$ & SD & 51 & 33,3 \\
$\mathbf{2}$ & SMP & 29 & 19,0 \\
$\mathbf{3}$ & SMA & 45 & 29,4 \\
$\mathbf{4}$ & Diploma & 10 & 6,5 \\
$\mathbf{5}$ & Sarjana & 18 & 11,8 \\
\hline \multicolumn{2}{|c|}{ TOTAL } & $\mathbf{1 5 3}$ & $\mathbf{1 0 0}$ \\
\hline
\end{tabular}

Berdasarkan tabel 3, menunjukkan bahwa dari 153 responden yang diteliti, sebagian besar responden berpendidikan SD sebanyak 51 responden $(33,3 \%)$, dan paling sedikit yang berpendidikan diploma sebanyak 10 responden $(6,5 \%)$.

Tabel 4 Distribusi Responden Berdasarkan Lama Dirawat Di RSUD Tani Dan Nelayan Kabupaten Boalemo

\begin{tabular}{|c|l|c|c|}
\hline No & \multicolumn{1}{|c|}{ Lama Dirawat } & $\mathbf{n}$ & $\mathbf{\%}$ \\
\hline $\mathbf{1}$ & 3-5 Hari & 117 & 76,5 \\
$\mathbf{2}$ & $>$ 5Hari & 36 & 23,5 \\
\hline \multicolumn{2}{|c|}{ TOTAL } & $\mathbf{1 5 3}$ & $\mathbf{1 0 0}$ \\
\hline
\end{tabular}

Berdasarkan tabel 4, menunjukkan bahwa dari 153 responden yang diteliti, sebagian besar responden lama perawatannya antara 3-5 hari sebanyak 117 responden (76,5\%), dan paling sedikit responden lama perawatannya antara > 5 hari sebanyak 36 responden $(23,5 \%)$.
Tabel 5 Distribusi Responden Berdasarkan Caring Perawat Di RSUD Tani Dan Nelayan Kabupaten Boalemo

\begin{tabular}{|c|c|c|c|c|c|c|c|}
\hline \multirow{2}{*}{ No } & \multirow{2}{*}{ Ruangan } & \multicolumn{4}{|c|}{ Caring Perawat } & \multirow{2}{*}{ Total } & \multirow{2}{*}{$\%$} \\
\hline & & Tinggi & $\%$ & Rendah & $\%$ & & \\
\hline 1 & $\begin{array}{l}\text { Interna } \\
1 \& 2\end{array}$ & 9 & 69,2 & 4 & 30,8 & 13 & 100 \\
\hline 2 & Interna 3 & 41 & 69,5 & 18 & 30,5 & 59 & 100 \\
\hline 3 & Bedah & 18 & 75 & 6 & 25 & 24 & 100 \\
\hline 4 & VIP & 6 & 100 & 0 & 0 & 6 & 100 \\
\hline 5 & Anak & 17 & 68 & 8 & 32 & 25 & 100 \\
\hline 6 & $\mathrm{ICU}$ & 18 & 69,2 & 8 & 30,8 & 26 & 100 \\
\hline & TOTAL & 109 & 71,2 & 44 & 28,8 & 153 & 100 \\
\hline
\end{tabular}

tabel 5, menunjukkan bahwa dari 153 responden yang diteliti, sebagian besar responden caring perawat tinggi sebanyak 109 responden $(71,2 \%)$ yang terdiri dari 9 responden $(69,2 \%)$ diruangan interna kelas $1 \& 2,41$ responden $(69,5 \%)$ diruangan interna kelas 3, 18 responden (75\%) diruangan bedah, 6 responden (100\%) diruangan VIP, 17 responden (68\%) diruangan anak, dan 18 responden $(69,2 \%)$ diruangan ICU. Sedangkan caring perawat rendah sebanyak 44 responden $(28,8 \%)$ yang terdiri dari 4 responden $(30,8 \%)$ di ruangan interna kelas $1 \& 2,18$ responden $(30,5 \%)$ diruangan interna kelas 3, 6 responden $(25 \%)$ di ruangan bedah, 8 responden (32\%) di ruangan anak, dan 8 responden $(30,8 \%)$ di ruangan ICU.

\section{Pembahasan}

Sebagian besar responden menjawab caring perawat tinggi pada pernyataan tentang perawat perhatian kepada pasien selama dirawat, perawat memberikan motivasi (semangat) kepada pasien untuk 
sembuh, perawat juga memperhatikan ketulusannya dengan tersenyum saat merawat pasien, perawat menganjurkan pasien untuk mengatakan apapun yang dikeluhkan atau yang dirasakan, perawat terlihat senang saat merawat pasien, perawat melakukan tindakan dengan tepat dan benar, dan perawat menganjurkan pasien untuk melakukan kegiatan keagamaan dalam menunjang kesembuhan pasien. Dari pernyataan tersebut yang paling banyak responden menjawab caring perawat tinggi di kuesioner tentang perawat selalu perhatian kepada responden selama merawat responden, perawat selalu memperhatikan ketulusannya dengan tersenyum saat merawat responden, dan perawat selalu menganjurkan responden untuk mengatakan apapun yang responden keluhkan atau yang responden. Dari pernyataan tersebut mencerminkan sepuluh faktor karatif Watson yang sesuai dengan jawaban dari pasien yang memiliki caring perawat tinggi yaitu sistem nilai humanistik dan alturistik : nilai-nilai humanistik, pembentukan sistem nilai humanistik dan alturistik yang menjelaskan sikap perawat yaitu harus menghormati pasien dan menghargai pasien dengan menerapkan nilai kebaikan, empati, cinta terhadap diri sendiri dan orang lain serta memberikan rasa nyaman kepada pasien selama pasien dirawat di rumah sakit. Bahwa seorang perawat berusaha untuk mengenal siapa kliennya, memberikan perhatian terhadap pasien, dan bagaimana seseorang perawat berperilaku sesuai dengan keadaannya.

Perawat mampu menggunakan diri dan pengetahuannya secara kreatif sebagai bagian dari proses caring perawat dalam menggunakan metode pemecahan masalah. Caring perawat yang dinilai tinggi oleh pasien merupakan gambaran dari pengalaman pasien terhadap pelayanan perawat selama pasien menjalani perawatan di rumah sakit. Kesan yang dialami oleh pasien selama menjalani perawatan dapat membantu pasien meningkatkan kesejahteraannya. Kesan buruk yang ditampilkan oleh perawat satu kali saja, dapat mempengaruhi persepsi pasien terhadap perawat selama pasien di rawat. (Yuliawati, 2012)

Sejalan dengan penelitian tersebut seperti dari Suryani (2010) dalam penelitiannya diruang bedah dewasa sebuah RS di Kota Palembang, mengemukakan hasil yang menunjukkan $51,5 \%$ pasien menilai perawat sudah caring terhadap pasien. Kurangnya pemahaman perawat terhadap konsep caring, citra profesi yang masih kurang, beban kerja yang tidak proporsional, dan kurangnya kesadaran perawat terhadap peran dan fungsi sesungguhnya dari profesi perawat.

Kedua penelitian tersebut di atas, penelitian ini juga menjadikan pasien sebagai objek penelitian. Sehingga didapatkan hasil penelitian caring perawat berdasarkan penilaian pasien terhadap caring yang dilakukan oleh perawat. 
Tingginya penilaian caring perawat menurut responden dalam penelitian ini merupakan suatu keadaan positif yang dapat memicu peningkatan kualitas pelayanan di RSUD Tani dan Nelayan Kabupaten Boalemo. Sebagai suatu pelayanan di RSUD Tani dan Nelayan Kabupaten Boalemo, penilaian positif dari pasien merupakan suatu penghargaan yang cukup baik, yang perlu dipertahankan dan dikembangkan agar dapat menciptakan citra yang baik dimata masyarakat. Tingginya caring perawat yang didapatkan dari hasil penelitian ini disebabkan karena sebagian besar perawat memiliki pengetahuan tentang caring perawat yang baik. Hal ini dapat dilihat dari tingkat pendidikan atau kualifikasi pendidikan dari perawat itu sendiri yang memiliki pendidikan S1 keperawatan ners sebanyak 34 perawat (Bidang Kepegawaian RSTN, 2018). Seperti yang dijelaskan oleh Koswara (2012) dalam penelititannya menemukan hubungan yang signifikan antara pengetahuan tentang perilaku caring dengan sikap caring perawat pelaksana.

Dalam analisa hasil penelitian terhadap caring perawat di ruangan VIP ditunjukkan sebanyak $100 \%$ responden mengatakan perawatnya caring tinggi. Hal ini di sebabkan karena faktor dari kebanyakan pasien yang masuk di ruangan VIP. Hal ini juga berdasarkan observasi yang dilakukan oleh peneliti karena jumlah tempat tidur diruangan VIP sebanyak 6 tempat tidur sedangkan jumlah personil perawat pelaksana sebanyak 10 perawat.
Berdasarkan perbandingan antara jumlah tempat tidur dan personal yang diterapkan berdasarkan keputusan Menteri Kesehatan No. 262/Menkes/Per/VII/79 idealnya RS tipe $\mathrm{C}$ perbandingannya 1 perawat : 1 tempat tidur. Penelitian ini sejalan dengan penelitian dari Dewi (2017) tentang gambaran caring perawat perawat di ruangan paviliun Rumah Sakit Daerah dr.Soebandi Jember. Dalam hasil penelitiannya didapatkan caring perawat sebagian besar dalam kategori baik sebanyak 65,6\%. Sedangkan diruangan interna kelas 1 \& 2 sebanyak 69,2\% responden termasuk kategori caring tinggi, diruangan intena kelas 3 sebanyak 69,5\% responden juga termasuk kategori caring tinggi, sama halnya pada ruangan bedah $75 \%$ responden, ruangan anak sebanyak $68 \%$ responden dan ruangan ICU sebanyak $69,2 \%$ semuaya termasuk dalam kategori tinggi.

Selain itu juga caring perawat tinggi bisa dilihat dari umur responden yang menjawab caring perawat tinggi. Bisa dilihat dari sebagian besar responden berumur rata-rata paling banyak adalah antara 26-35 tahun sebanyak 63 responden $(41,2 \%)$, dan paling sedikit yang berumur 12-16 tahun sebanyak 2 responden $(1,3 \%)$. Hasil penelitian ini sejalan dengan penelitian Anjaswarni (2013) yang dilakukan terhadap 125 orang pasien di ruang rawat inap dewasa RSUD di Kota Malang. Dalam penelitiannya mendapatkan rata-rata umur responden 25-35 tahun. Usia ini termasuk usia produktif yang 
secara psikologis telah mencapai

perkembangan kognitif yang optimal. Peneliti berpendapat bahwa responden yang dengan usia produktif secara psikologis memiliki kemampuan untuk memberikan penilaian yang secara objektif terhadap pengalaman mendapatkan caring perawat selama pasien berada di rumah sakit.

Dalam hal ini caring perawat yang tinggi diperlukan untuk meningkatkan kualitas pelayanan keperawatan yang bertujuan untuk meningkatkan kesejahteraan pasien. Izumi dkk (2010) menyebutkan bahwa caring merupakan salah satu dominan dari kualitas pelayanan keperawatan. Sebagai inti dari keperawatan, caring hendaknya dijadikan landasan bagi perawat dalam melakukan asuhan terhadap pasien untuk memenuhi harapan dan tuntutan masyarakat.

Berdasarkan hasil penelitian pada kategori caring perawat rendah sebanyak $28,8 \%$ responden. Hal ini dikarenakan dari hasil yang didapatkan oleh peneliti bahwa caring perawat itu rendah yang dapat dilihat dari banyaknya pernyataan responden yang menjawab caring perawat rendah pada kuesioner yang isinya jika bejanji perawat cenderung lupa menepati janjinya, perawat tidak pernah menganjurkan pasien untuk bertanya tentang penyakitnya, perawat tidak pernah memberikan jawaban yang memuaskan ketika pasien bertanya tentang kondisinya, perawat menolak memberikan penjelasan tentang kondisi pasien ketika pasien meminta penjelasan. Dalam hal ini pernyataan tersebut termasuk dalam karatif watson yang hubungan saling percaya dan membantu : Mengembangkan hubungan saling percaya dan membantu. Dimana perawat diminta untuk membina hubungan saling percaya, jujur dan empati dalam menjalin hubungan interpersonal yang terapeutik dengan tujuan menolong orang lain. Dalam hal ini perawat tidak melakukkannya.

Caring perawat rendah juga salah satunya dipengaruhi oleh faktor beban kerja. Hal ini dibuktikan dengan banyaknya pernyataan yang dijawab oleh pasien bahwa perawat tidak segera datang jika pasien butuhkan dan perawat terlihat sibuk sehingga waktu untuk merawat pasien menjadi berkurang. Hal ini juga menunjukkan caring perawat rendah sebanyak 18 responden $(30,5 \%)$ dari total responden pada ruangan interna kelas 3 sebanyak 59 responden. Dengan jumlah personil perawat diruangan tersebut sebanyak 14 perawat sedangkan kapasitas tempat tidur sebanyak 30 bed dan BOR nya perhari 86.

Penelitian ini juga sejalan dengan penelitian dari Iikafah dan Harniah (2017) tingginya beban kerja sebanyak 40 responden menyatakan beban kerja rendah $(75,5 \%)$ yang dilakukan oleh perawat menyebabkan tingginya stres yang terjadi pada perawat sehingga menurunkan motivasi perawat untuk melakukan caring. Juliani (2015) menyampaikan ada hubungan yang signifikan antara beban kerja perawat 
dengan pelaksanaan caring perawat. Beban

kerja yang tinggi menyebabkan kelelahan pada perawat sehingga dapat menurunkan motivasi perawat untuk bersifat caring. Tingginya beban kerja menyebabkan perawat memiliki waktu yang lebih sedikit untuk memahami dan memberikan perhatian terhadap pasien secara emosional dan hanya fokus terhadap kehiatan yang bersifat rutinitas, seperti memberikan obat, melakukan pemeriksan lanjutan, atau menulis catatan perkembangan pasien.

Selain faktor beban kerja, tingkat pendidikan juga mempengaruhi cairng perawat rendah. Sebagian besar responden yang menjawab caring rendah yaitu tingkat pendidikannya antara SMA sebanyak 15 responden, Diploma dan Sarjana sebanyak 6 responden. Dimana faktor pendidikan sangat berpengaruh pada penilaian seseorang terhadap suatu perilaku caring yang dilakukan perawat pada pasien. Menurut penelitian dari Agustin (2012) yang menemukan bahwa adanya kecenderungan pasien dengan tingkat pendidikan yang rendah memiliki tingkat kepuasan yang lebih rendah dibandingkan pendidikan yang tinggi. Hal ini sejalan dengan penelitian yang dituturkan oleh Setiawati (2015) mendapatkan hasil penelitian dengan tingkat pendidikan responden sebagian besar adalah pendidikan SMA dan juga sarjana. Tingkat pendidikan mempengaruhi persepsi pasien terhadap kualitas pelayanan keperawatan. Pendapat ini didukung oleh Radwin (2013) yang menyatakan bahwa individu yang memiliki pendidikan tinggi umumnya telah mendapatkan banyak informasi tentang pelayanan kesehatan, serta cenderung memiliki harapan yang lebih tinggi terhadap pelayanan kesehatan. Pasien dengan tingkat pendidikan tinggi biasanya menginginkan pelayanan yang lebih baik sesuai dengan harapan mereka, ingin lebih dihargai pendapatnya, lebih diperhatikan dan biasanya akan lebih banyak mencari tahu tentang kondisi penyakitnya.

Selain itu juga lamanya hari rawat berpengaruh pada caring perawat menjadi rendah, penelitian ini mendapatkan bahwa rata-rata lama hari rawat responden adalah 3-5 hari. Dibuktikan dengan rata-rat responden dengan menjawab caring perawat rendah adalah pasien dengan lama hari rawat 3-5 hari sebanyak 39 responden. Penelitian sebelumnya yaitu Zuhry (2013) yang dilakukan di Rumah sakit daerah Solok dengan jumlah responden 111 orang mengelompokan pasien bedasarkan lama hari rawat antara 3-5 hari dan lebih dari 5 hari dikarenakan pasien dengan lama hari rawat diatas 5 hari cenderung lebih efisien menilai caring dari seorang perawat karna kontak langsung dengan perawat lebih lama dibandingkan dengan dibawah 5 hari rawat. Pendapat ini didukung oleh penelitian Sukesi (2012) yang menemukan bahwa lama hari rawat dibawah 5 hari memiliki kecenderungan mempersepsikan perilaku perawat lebih rendah daripada pasien dengan lama hari rawat yang lebih panjang.

Peneliti berpendapat bahwa lama hari rawat berpengaruh pada persepsi dan penilaian pasien terhadap perilaku caring perawat, 
karena pengalaman individu tentang situasi tertentu dapat menimbulkan persepsi dan penilaian berbeda. Selama perawatan, pasien menerima perlakuan dan pelayanan dari perawat, dan bagaimana perawat bersikap selama memberikan asuhan keperawatan. Hal ini sejalan dengan penelitian dari Fadilah (2016) yang menjelaskan bahwa ada hubungan caring perawat dalam pelayanan keperawatan dengan lama rawat inap dengan signifikan 0,009 dengan arah hubungan positif sekitar 0,501. Seorang perawat berusaha untuk mengenali siapa kliennya, memberikan perhatian terhadap pasien dan bagaimana seseorang perawat berperilaku sesuai dengan keadaan. Bentuk nyatanya adalah mengenali nama pasien, mengenali kelebihan dan karakteristik pasien, memanggil nama dengan nama yang disenangi, mendahulukan kepentingan pasien daripada kepentingan pribadi, menyediakan waktu bagi pasien walaupun sedang sibuk, mendengarkan keluhan dan kebutuhan pasien, menghargai dan menghormati pendapat pasien, memberikan dukungan sosial untuk memenuhi kebutuhan dan meningkatkan status pasien.

\section{Simpulan}

Dari 153 responden di RSUD Tani dan Nelayan Kabupaten Boalemo caring perawat tinggi sebanyak 109 responden $(71,2 \%)$ dan caring perawat rendah sebanyak 44 responden $(28,8 \%)$.

\section{Daftar Pustaka}

Agustin, I. 2012. Perilaku Caring Perawat dan Hubungannya dengan Kepuasan Klien di Instalasi Rawat Inap Bedah Dewasa RS Dr. Muhammad Hoesin Palembang. Program Pasca Sarjana FIK UI. Tesis

Anjaswarni, T. 2013. Analisis Tingakat Kepuasan Klien Terhadap Perilaku Caring Perawat di Rumah Sakit Umum Daerah Dr. Saiful Anwar Malang. Program Pasca Sarjana Fakultas Ilmu Keperawatan Universitas Indonesia. Tesis

Ardhyatama, Rianja Ikhwan. 2018. Hubungan Caring Perawat dengan Kesiapan Keluarga Menerima Informasi Kesehatan Tentang Terapi Lanjutan di Ruang Mawar RSUD Jombang. Skripsi

Ardiana, 2010. Hubungan Kecerdasan Emosional Perawat dengan Perilaku Caring Perawat Pelaksana Menurut Persepsi Pasien di Ruang Rawat Inap RSU dr. H. Koesnandi Bondowoso. Depok : Universitas Indonesia

Azizah, M.L. 2013.Hubungan Pelaksanaan Komunikasi Terapeutik Perawat Dengan Tingkat Kepuasan Pasien Di Ruang Rawat Inap Melati RSUD Subang. Cimahi : STIKKES Jendral Achmad Yani

Blais, Kathleen Koenig. 2007. Praktek Keperawatan Profesional Konsep Dan Prespektif. Jakarta : EGC

Darmawan, Ngurah. 2017. Hubungan Perilaku Caring Perawat Terhadap Tingkat Kepuasan Pasien Rawat Inap Di RSUD Klungkung. E-Journal

Dewi, Yulianti Kurnia. 2017. Gambaran Perilaku Caring Perawat Di Ruang Paviliun Dan Ruang Rawat Inap Kelas III RSUD DR. Soebandi Jember. Skripsi

Firmansyah, et al. 2019. Perilaku Caring Berdasarkan Teori Jean Watson Di Ruang Rawat Inap. Jurnal Kesehatan Vokasional

Gadow, S. 2010. Touch And Technology ; Two Paradigmas of Patient Care. Journal Of Religion And Helath

Hidayat, 2008. Pengantar Konsep Dasar Keperawatan Edisi 2. Jakarta : Salemba Medika

Iikafah \& Harniah, 2017. Perilaku Caring Perawat Dengan Kepuasan Pasien Di Ruang Rawat Inap Private Care Centre 
RSUD DR Wahidin Sudirohusodo

Makassar. Makassar : Universitas Hasanuddin

Izumi, S., Baggs, J.G., Knafl, K.A. 2010. Quality Nursing Care for Hospitalized Patients With Advanced Illness: Concept Development. Research in Nursing \& Health 33 299-315.

Juliani, Suparni \& Rustika. 2015. Hubungan Karakteristik Responden dan Perilaku Caring Perawat dengan Kepuasan Pasien Rawat Inap di RS PGI Cikini. Jakarta : STIK SINT Carolus

Kemenkes RI, 2010. Standar Pelayanan Minimum Rumah Sakit. Jakarta

Koswara, D. 2012. Hubungan Antara Pengetahuan Caring Dengan Sikap Caring Perawat Pelaksana di Ruang Rawat Inap RSUD Tasikmalaya. Program Pasca Sarjana FIK UI. Tesis

Kozier, dkk. 2010. Fundamental Of Nursing : Concepts, Process, And Practice. Jakarta :EGC.

Kusumarini, E. 2016. Faktor-Faktor yang Mempengaruhi Perilaku Caring Perawat Ruang Sulaiman 3 dan 4 RS Soemani Muhammadiyah Semarang. Skripsi

Mony, D.N. 2014.Hubungan Sikap Caring Perawat Dengan Kepuasan Pasien Di Rawat Inap Kleas III Di Rumah Sakit PKU Muhammadiyah Yogyakarta.Skripsi.

Morrison, Paul. 2009. Caring And Communicating Alih Bahasa Widyawati Edisi 2. Jakarta : EGC

Notoatmodjo, 2012. Metodologi Penelitian Kesehatan Cetakan Kedua. Jakarta : Rineka Cipta

Nursalam. 2011. Proses Dan Dokumentasi Keperawatan, Konsep Dan Praktek. Jakarta : Salemba Medika

Perry. 2012. Basic Nursing Essentials For Practise $6^{\text {th }} \mathrm{Ed}$. Canada : Mosby Elsevier

Purwaningsih, Diah Fitri. 2018. Perilaku Caring Perawat Pelaksana Di Ruang Rawat Inap. E-Journal

Purwoastuti, 2015. Perilaku dan Softskills Kesehatan Panduan Untuk Tenaga Kesehatan (Perawat dan Bidan). Yogyakarta : Mitra Cendikia Pres

Radwin, L. 2013. Oncology Patients Perceptions of Quality Nursing Care. Res Nurse Health
Ramadhiani, O.R., \& Siregar, T. 2019. Hubungan Berpikir Kritis Dengan Kepedulian (Caring) Perawat Dalam Melaksanakan Asuhan Keperawatan Di RSUD Kota Depok. Jurnal Kedokteran Dan Kesehatan

Rivai, V \& Mulaydi, D. 2015. Kepemimpinan dan Perilaku Organisasi. Jakarta : PT Raja Grafindo Persada

Rozalina, Anisa \& Deby. 2017. Gambaran Perilaku Caring Perawat Pelaksana Di Ruang Bedah RSUD Panembahan Senopati Bantul. Skripsi

Setiawati. 2015. Analisis Faktor-Faktor yang Berhubungan Dengan Kepuasan Klien Terhadap Perilaku Caring Perawat Pelaksana Di Instansi Rawat Inap Pusat Medic RS Imanuel Bandung. Program Pasca Sarjana FIK UI. Tesis

Sitorus. 2013. Model Praktek Keperawatan Profesional Di Rumah Sakit. Jakarta : EGC

Sugiyono, 2010. Metode Penelitian Pendidikan Pendekatan Kuantitatif, Kualitatif, dan $R \& D$. Bandung : Alfabeta

Sumartini, T. 2017.Hubungan Perilaku Caring Perawat Dengan Kepuasan Pasien JKN Di Instalasi Rawat Inap Kelas III RSUD Pandan Arang Boyolali. Skripsi

Sunaryo. 2013. Psikologi Dalam Keperawatan. Jakarta : EGC

Supriatin, E. 2015.Perilaku Caring Perawat Berdasarkan Faktor Individu Dan Organisasi. Jurnal Keperawatan Indonesia

Suryani, 2010. Hubungan Lingkungan Kerja dengan Perilaku Caring Perawat di RS PGI Cikini Jakarta. Depok : Universitas Indonesia

Susanto, 2012. Buku Ajar Keperawatan Keluarga Aplikasi Teori pada Praktik Asuhan Keperawatan Keluarga. Jakarta : TIM

Tiara, \& Lestari, A. 2014. Perilaku Caring Perawat Dalam Meningkatkan Kepuasan Pasien Rawat Inap. Jurnal Keperawatan

Tomey \& Alligood, 2006. Nursing Theorists and Their Work. USA : Mosby Elsevier

Undang-Undang Kesehatan Nomor 23 tahun 1992 tentang Keperawatan

Undang-Undang Republik Indonesia Nomor 38 Tahun 2014 Tentang Keperawatan

Wasis, 2008. Pedoman Riset Praktis untuk Profesi Perawat. Jakarta : EGC 
Watson, J. 2010. Assessing And Measuring

Caring in Nursing Management And

Health Science. Boston : JonesAnd Barlet

Publisher

Wong et al, 2009. Buku Ajar Keperawatan Pediatrik Edisi 6 Volume 2. Jakarta : EGC

Yariq, L. 2019. Hubungan Berpikir Kritis Dengan Perilaku Caring Perawat Dalam Pelayanan Kesehatan

Yuliawati, 2012. Gambaran Perilaku Caring Perawat terhadap Pasien di Ruang Rawat Inap Umum RS dr. H. Marzoeki Mahdi Bogor. Depok: Universitas Indonesia 